Pamiętnik Literacki 2019, 4, s. 255-268

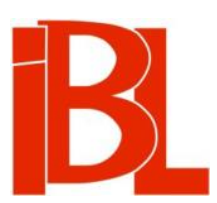

Style odbioru polskiej powieści o Zagładzie. Wokól "Tworek" Marka Bieńczyka i “Fabryki muchołapek" Andrzeja Barta

Marta Tomczok 
Pamiętnik Literacki CX, 2019, z. 4, PL ISSN 0031-0514

DOI: $10.18318 /$ pl.2019.4.17

MARTA TOMCZOK Uniwersytet Śląski, Katowice

\section{STYLE ODBIORU POLSKIEJ POWIEŚCI O ZAGEADZIE WOKÓ£ „TWOREK” MARKA BIEŃCZYKA I „FABRYKI MUCHOŁAPEK” ANDRZEJA BARTA}

Literatura jest jak fosfor. Najbardziej błyszczy, gdy ma już zgasnąć ${ }^{1}$.

Ukształtowane w pracach Michała Głowińskiego pojęcie stylu odbioru, przez które badacz rozumiał „normy lektury układające się w pewien system i określające charakter właściwych danemu czasowi konotacji literackich"2, może stanowić niezwykle wartościowe narzędzie $\mathrm{w}$ analizie rozumienia powieści o Zagładzie przez publiczność literacką. W artykule postaram się pokazać, w jaki sposób formułowano oczekiwania wobec „formy niemożliwej” (tak przez lata nazywano w studiach nad Holokaustem powieść o nim) i jakie stawiano jej zadania. Nie będę śledzić losów wszystkich polskich powieści - wymagałoby to osobnego, obszernego studium a jedynie recepcję dwu szeroko dyskutowanych: Tworek Marka Bieńczyka (1999) i Fabryki muchołapek Andrzeja Barta (2008). Z recenzji i artykułów na ich temat wyłania się istotna zmiana w postrzeganiu roli powieści podejmujących temat Zagłady: na przełomie mileniów przestają czytelników zajmować kategorie estetyczne związane ze stosownością i formą oraz absolutyzowaną w studiach nad Holokaustem ideą niemożności pisania o nim, zaczyna ich natomiast interesować to, co powieść ma do powiedzenia, czyli historia i jej interpretacje. Jak pokazują losy prozy Barta, gatunek ten może być przedmiotem prac historyków, oczekujących od tekstu literackiego cech przynależnych historiografii, takich jak obiektywizm czy wielostronna ocena przedstawianych zdarzeń, poparta wcześniejszymi badaniami.

W prowadzonych od końca wojny rozważaniach na temat roli powieści o Zagładzie uwzględniano, pozbawiony równowagi, stosunek fikcji do dokumentaryzmu. Otwarty charakter wspomnianej formy, jak twierdził Roger Caillois, przesądził o tym, że „wszystko jej wolno. Żadna ars poetica o niej nie wspomina i nie dyktuje jej praw"3. Francuski eseista zestawił tu, oczywiście, powieść $z$ normatywną poetyką klasycystyczną, opartą na ścisłych regułach i na podziale gatunków. Tymczasem narracja zagładowa preferowała formę dogodną dla przedstawienia faktów, sprzy-

1 R. B a r th e s, Le Degré zero de l'écriture. Paris 1953, s. 57. Cyt. za: K. B a r to s zy ń s ki, Kryzys czy trwanie powieści. Studia literaturoznawcze. Kraków 2004, s. 149.

2 M. Gło w in s k ki, Odbiór, konotacje, styl. W: Dzieło wobec odbiorcy. Szkice z komunikacji literackiej. Kraków 1998. Prace wybrane Michała Gtowińskiego. Red. R. Ny c z. T. 3, s. 129.

3 R. Ca a illo i s, Siła powieści. Przekł., posł. T. S w o b o d a. Gdańsk 2008, s. 21. 
jała opowieściom świadków o różnych kompetencjach kulturowych i odmiennym wykształceniu, dawała pierwszeństwo swobodzie, zachowując przy tym elementarne zasady opowiadania.

Problemem w przyswojeniu powieści przez kulturę poholokaustową mogła być także jakość nazywana przez część badaczy powieściowością, a zatem ideą, którą w pisarstwie Rolanda Barthes'a wyodrębnił Marek Bieńczyk, wiążąc ją z uporczywym dążeniem do zapisywania codziennych wydarzeń oraz do przekształcania ich w figury i chwyty retoryczne (anakoluty, aforyzmy, epifanie), rozumiane jako składniki literackości ${ }^{4}$. Wszystko to uczyniło powieść kategoria porządkowania świata niezależną wobec pojęć formy i gatunku, narzucania mu odgórnego sensu i pewnej wizji czy - jak to określał w Rue des Écoles Bieńczyk - „składniowej weryfikacji [...], odnalezienia jego składni” ${ }^{5}$.

W pierwszym polskim artykule poświęconym w całości zagadnieniu literatury wobec Zagłady Głowiński nazwał gatunkiem koronnym tego piśmiennictwa nie powieść, lecz opowiadanie. Powodem takiego wyboru okazała się adekwatnie pojemna i elastyczna forma tego gatunku, któremu najbliżej jest do dokumentu i który pozwala na „przedstawienie poszczególnych losów w sposób konkretny, bez troski o skomplikowane konstrukcje fabularne - niejako ze swej natury bliskie [...] sprawozdaniu, relacji o fakcie, wspomnieniu, rozumianemu jako swoisty gatunek, czy reportażowi" ${ }^{\circ}$. Za pomoca cech stanowiących o sile opowiadania można - na zasadzie przeciwieństwa - opisać również powieść, szczególnie zaś tę jej odmianę, która łączy się z Zagłada. Charakteryzowałyby ją: daleko posunięta fikcyjność, niekonkretność, polegająca na dominacji stylu antymimetycznego czy groteskowego, a także różnych innych form wypowiedzi opartych na umowności, złożona, wielopoziomowa konstrukcja fabularna, dystans wobec popularnych postaci literatury faktu, takich jak reportaż, i niesprawozdawczość. Fundamentalne właściwości opowiadania, czyli relacjonowanie zdarzeń i „przystępność” języka, nie skupiającego na sobie nadmiernej uwagi, wydają się lekceważone przez powieść o Zagładzie. Wyjątkiem sa tu utwory wybitne: Czarny potok Leopolda Buczkowskiego, Chleb rzucony umartym Bogdana Wojdowskiego ${ }^{7}$ czy Oczekiwanie Jerzego Broszkiewicza $^{8}$. Jednak większość owej prozy nie tylko nie zawiera w sobie adekwatnie przezroczystej narracji, ale też nie czyni zdarzeń i faktów najistotniejszym przedmiotem opowiadania historii, podczas gdy to właśnie prawda historyczna

4 M. Bieńczy k, Rue des Écoles [o nich tutaj]. „Literatura na Świecie” 2004, nr 1/2, s. 421-422. Dwoistemu rozumieniu literackości w studiach nad Zagłada i w pisarstwie holokaustowym K. Ch mi elew s k a poświęciła studium Literackość jako przeszkoda, Literackość jako możliwość wypowiedzenia (w zb.: Stosowność i forma. Jak opowiadać o Zagładzie? Red. M. Głowińs ki [i in.]. Kraków 2005). Zauważała w nim m.in.: „Kategoryczne odrzucenie poezji po Auschwitz, traktowanie literatury jako bluźnierstwa, jako karygodnego przetworzenia Holokaustu, które z konieczności kończy się porażką, powtarza się w różnych wariantach i stało się leitmotivem rozważań o Zagładzie. Odrzucenie to spotyka się jednak z tendencją przeciwną, która przejawia się w ciagłym poszukiwaniu właściwych środków, w modyfikacjach poetyk i strategii literackich, ale przede wszystkim w coraz obfitszej twórczości literackiej” (ibidem, s. 21).

5 Bieńczyk, op. cit., s. 432.

6 M. Głowiński, Wprowadzenie. W zb.: Stosowność i forma, s. 11.

7 Zob. ibidem, s. 248.

8 Zob. ibidem, s. 11. 
powinna stanowić cel każdego przedstawienia Zagłady. Tylko „prawdziwym” narracjom udaje się osiągnąć równowagę między dokumentaryzmem a fikcją. Spójność narracyjna, właściwa przede wszystkim dokumentom, znacznie rzadziej odnosi się do powieści. Jak stwierdził Berel Lang:

W przeciwieństwie do dzienników czy wspomnień powieść nie jest zwykle postrzegana w pierwszym rzędzie jako forma pisarstwa historycznego; jest rodzajem bardziej elastycznym i otwartym na zmiany (na przykład posiada więcej różnorodnych możliwości kreowania autorskiego punktu widzenia, fabuły, postaci). Jest zatem bardzo znaczące, że w wielu powieściach o nazistowskim ludobójstwie owe możliwości są ograniczone wymogiem prawdy historycznej - fakt szczególnie widoczny w utworach, które pod każdym innym względem ściśle przestrzegają konwencji gatunku ${ }^{9}$.

Antymimetyczne cechy powieści, omawiane dalej w związku z utworami Bieńczyka i Barta, stanowią według Langa o jej słabości i przekładają się na zjawisko określane przez badacza mianem „wyolbrzymienia”. Oznacza ono „nieproporcjonalnie dużą rolę historycznego kontekstu"10, zbyt częste powiadamianie odbiorcy o historyczności komunikatu, prawdziwości relacjonowanych zdarzeń czy powinnościach literatury, definiującej samą siebie w kategoriach świadectwa, a nie artefaktu. Powieści, pisze Lang, zanadto zależy na tym, by ukryć własną powieściowość, dlatego tak ostro i definitywnie broni ona prawdy, zdradzajacc się $z$ własna sztucznością. Szczególnie widoczne jest to w formach podrabiających i prze-pisujących gatunki literatury dokumentu osobistego: dziennikach, wspomnieniach lub autobiografiach ${ }^{11}$. W skrajnej postaci służą one zatajaniu prawdy i powstawaniu fałszerstw historycznych ${ }^{12}$.

Zasadnicza wątpliwość, czy rozpatrywany gatunek może w sposób przekonujący opowiadać o Zagładzie, skonfrontowana $\mathrm{z}$ rzeczywistością literacką, składającą się $\mathrm{z}$ setek tego rodzaju tekstów, przestaje dziwić chociażby w odniesieniu do przykładów przywołanych na początku. Praktyka pisarska unaocznia, że od czasu zakończenia drugiej wojny światowej powieść nie tylko wykształciła dziesiątki sposobów mówienia o Holokauście, ale też, że część z nich okazuje się fortunna i skutecznie oddziałuje na myślenie społeczeństwa o historii. W artykule Klęska powieści. Wybrane strategie pisania o Szoa, zastanawiając się nad pytaniem, „czy powieść o Szoa jest bluźniercza"13, Katarzyna Chmielewska przekonywała:

Powieść jest formą wyjątkowo pojemną. Udzielenie odpowiedzi generalnej jest więc nonsensem. Nie można orzec, że powieść jako taka jest formą stosowną lub nie. Można natomiast p rześledzić poszczególne strategie powieściowe i zastanowić się, dlaczego jedne z nich wydają się trafne, inne zaś całkowicie chybione. Pierwszy i zasadniczy problem, z którym musi się zmierzyć historyk literatury, stanowią kryteria samej stosowności ${ }^{14}$.

\section{s. $145-146$.}

10 Ibidem, s. 146.

11 Zob. ibidem.

12 Zob. R. Franklin, A Thousand Darkness: Lies and Truth in Holocaust Fiction. Oxford 2011. S. V i c e, Textual Deceptions: False Memoirs and Literary Hoaxes in the Contemporary Era. Edinburgh 2014.

13 K. Ch mi el ew s ka, Klęska powieści? Wybrane strategie pisania o Szoa. W zb.: Stosowność i forma, s. 248. 
Idąc za głosem Chmielewskiej, proponuję zrekonstruować recepcję dwu powieści wymienionych na wstępie, które - przypomnę - uznać należy za najbardziej dyskutowane i najczęściej opisywane teksty fikcyjne o Zagładzie w latach dziewięćdziesiatych XX wieku i dwutysięcznych. Czynnikiem pozwalającym zobaczyć w tych, a nie innych dziełach literackich obiekt badań nie jest wyłącznie liczba recenzji czy rozpraw naukowych napisanych na ich temat, ale ich ranga, poziom i zakres podejmowanych przez nie problemów bądź też, przynajmniej częściowo, liczba cytowań tych publikacji oraz fakt, iż publikowane one były na łamach najważniejszych pism literaturoznawczych w Polsce (takich jak „Pamiętnik Literacki”, „Ruch Literacki” czy „Teksty Drugie”). U podstaw podjętej tu analizy leży przekonanie, że z recepcji Tworek i Fabryki muchołapek można wyabstrahować preferowane i odrzucane style pisania o Zagładzie; style, które spotkały się w Polsce i z uznaniem, i z niechęcią; style odzwierciedlające poglądy polskiej publiczności literackiej, jej zapatrywania na relację między opowiadaniem o przeszłości a wiedzą historyczną oraz filozofia podejmującą temat Holokaustu, a także tym, co powinno być tabuizowane, nieomawiane, skrywane.

Jak przekonywał w artykule Konstrukcja a recepcja. (Wokót „Dziejów grzechu” Żeromskiego) Głowiński:

Badanie recepcji dzieł literackich w danej epoce czy w danym kręgu społecznym lub literackim to zwykle domena bezproblemowych opisów, jakby ten dział historii literatury z samej swej istoty miał być zarezerwowany dla czystej faktografii. Wydaje się wszakże, iż i ta dziedzina zainteresowań powinna stać się przedmiotem refleksji teoretycznej, stawia bowiem przed historykiem literatury niejedno ciekawe i ważne zagadnienie ${ }^{15}$.

Uzupełniając owe założenia, Chmielewska dowodzi, że studia nad recepcją, pojmowane jako część historii literatury, nastręczają badaczowi wielu problemów, takich jak rozpatrywanie i zestawianie niezliczonych, indywidualnych głosów na temat dzieła, nie dających się uporządkować i scalić:

Niemożność uwzględnienia nieskończonego przecież zróżnicowania wszelkich publiczności albo

rozważali stosunkowo rzadko. Mimo istnienia wielu prac poświęconych nadużyciom w literaturze, szczególnie popularnej, skupionych wokół pornografizacji i kiczu, studiów poświęconych expressis verbis wspomnianej kategorii powstało niewiele. Jednym $z$ najistotniejszych jest praca A. H. Rosenfelda Podwójna śmierć. Rozważania o literaturze Holocaustu (Przeł. B. Kraw cowicz. Warszawa 2003, s. 221, 228), w której mówi się m.in. o niestosownych przedstawieniach erotyki w Wyborze Zofii W. Styrona oraz o niestosownym komizmie w Królu żydowskim L. Epsteina. O niestosowności w ukazaniu Zagłady Żydów ukraińskich i obozu w Treblince w odniesieniu do kontrowersyjnej powieści H. Demidenko (właśc. H. Dale) The Hand that Signed the Paper i budzacego wiele wątpliwości Białego Hotelu D. M. Thomasa pisała S. Vice w Holocaust Fiction (New York - London 2000, s. 148). S. B u ry ł a (Wokół Zagłady. Szkice o literaturze Holokaustu. Kraków 2016, s. 97-98) uznał za niestosowną powieść A. Czerskiego Nieśmiertelni (chodziło o przedstawienie w niej komory gazowej), natomiast T. Mizerki ewi c z (Literatura obecna. Szkice o najnowszej prozie i krytyce. Kraków 2013, s. 158) jako naruszająca granice decorum pokazał scenę palenia żydowskimi dziećmi w lokomotywie, opisana przez K. Piwowarskiego w zbiorze opowiadań Więcej gazu, Kameraden! (wspominam o tym przykładzie, mimo że pochodzi on z opowiadania, a nie $\mathrm{z}$ powieści, by zaznaczyć, iż refleksje wokół stosowności mają często charakter krótkich uwag, a nie obszernych studiów).

15 M. Głow in s k i, Konstrukcja a recepcja. (Wokót „Dziejów grzechu” Żeromskiego). W: Dzieło wobec odbiorcy, s. 169. 
jednostkowych czytelników skazuje projekt nowej historii literatury na nieuchronną arbitralność, przypadkowość i fragmentaryczność, historyczne publiczności nie tworzą bowiem wspólnej perspektywy. Jest to problem nieco ogólniejszy. Teoretycy oddziaływania zdają się niekiedy zapoznawać fakt niesymetryczności autora i czytelnika, mówiąc najprościej: zapominają o tym, iż autor jest jeden, czytelników zaś wielu i nie sposób ich traktować jako symetrycznego odzwierciedlenia nadawcy. Dlatego też teoretycy tego kierunku nie dostrzegają, że jeśli przyjmie się za punkt wyjścia realną publiczność, realnego czytelnika bądź też potencjalnego odbiorcę zewnątrztekstowego, to nie sposób uzyskać jakiejkolwiek jednorodnej perspektywy, z której można by ujmować historię literatury jako całość ${ }^{16}$.

\section{Herman Kinder i Heinz-Dieter Weber stwierdzają zaś:}

największą różnorodność interpretacji pociagaja za sobą zazwyczaj teksty, które w poszczególnych fragmentach wydają się jasne, jako całość stanowią jednak zagadkę, przy czym poszczególni interpretatorzy mogą ewentualnie odczuwać ich jednoznaczność lub ją deklarować ${ }^{17}$.

Do takich tekstów należą Tworki i Fabryka muchołapek, będące - mimo wielu trafnych interpretacji - powieściami niedoczytanymi, polisemicznymi, pozwalającymi się dekodować na różne sposoby w zależności od kontekstu. Chociaż „nigdy nie można $\mathrm{z}$ pewnościa przewidzieć, jakie będzie oddziaływanie lektury" ${ }^{18}$, da się poczynić na ten temat wstępne założenia na podstawie kontekstu wspólnego dla określonej grupy czytelników. W przypadku prozy Bieńczyka i Barta jest to, z jednej strony, kontekst filozoficzny, stworzony na fundamencie najbardziej znanych i najczęściej przywoływanych w Polsce w latach 1999-2013 ${ }^{19}$ lektur filozoficznych dotyczących Zagłady (zwłaszcza rozpraw Jeana-François Lyotarda oraz Jeana-Jacques'a Derridy), z drugiej zaś - kontekst kulturowy. Idąc za myślą Anny Jarmuszkiewicz, rozważającej prace Harolda Blooma, Marii Delaperrière i Stanleya Fisha, można powiedzieć, że drugi ze wspomnianych kontekstów powstaje tu w obrębie określonych wspólnot interpretacyjnych jako spoiwo ich wizji świata, a także pewien stały układ odniesienia. Dlatego niektóre właściwości dzieli z pamięcią kulturową 20 .

Recepcja stanowi [...] zbiór [...] interpretacji powstałych jako odczytania historyczne (rozłożone w czasie) i jako ślady lektury wspólnot interpretacyjnych, które są nadal i nieustannie realizowane synchronicznie $^{21}$.

K. Ch mi ele w s ka, Ukryte założenia i aporie teorii recepcji. „Pamiętnik Literacki” 2001, z. 4, s. 10. H. K in d e r, H.-D. W e b e r, Badania literaturoznawcze nad recepcja zorientowana na działanie. W zb.: Wspótczesna myśl literaturoznawcza $w$ Republice Federalnej Niemiec. Antologia. Wybór, oprac., wstęp H. Orłowski. Warszawa 1986, s. 279 (przeł. W. Bialik).

Ibidem, s. 286.

Badany okres recepcji przyjmuję za słownikiem internetowym Polscy pisarze $i$ badacze literatury przełomu XX i XXI wieku, dostępnym na stronie: http://www.ppibl.ibl.waw.pl/mediawiki/index. php?title=Lista_hase\%C5\%82 (data dostępu: 17 X 2019). Hasła Andrzej Bart i Marek Bieńczyk, przygotowane przez M. S ę c z ek i B. D or o s z, oprócz biogramów pisarzy zawierają listę publikacji na temat ich twórczości. W odniesieniu do Fabryki muchołapek zgromadzono 18 recenzji i artykułów naukowych, na temat Tworek - 30. Oba hasła są na bieżąco aktualizowane (hasło Andrzej Bart ostatni raz 17 VI 2019, hasło Marek Bieńczyk - 8 II 2019).

Zob. A. J a r m u s z k i e w i c z, Tropy Prousta. Problemy recepcji literackiej $w$ literaturze polskiej po 1945 roku. Kraków 2019.

A. J a rmuszkiewicz, Wspótczesne badania nad recepcją literacka $w$ kontekście literatury światowej oraz pamięci kulturowej. W zb.: Mapy świata, mapy ciała. Geografia i cielesność $w$ literaturze. Red. A. J a strzę b ska. Kraków 2014, s. 15. 
Przeanalizowanie aktów lektury powieści Bieńczyka i Barta pozwala opisać dominujące w ostatnich latach style odbioru powieści o Zagładzie, lecz zarazem przynosi odpowiedź na pytanie, dlaczego akurat te, a nie inne dzieła stały się przedmiotem wzmożonej refleksji historyków literatury. Tworki i Fabryka muchołapek okazują się artefaktami nie tylko budzącymi wątpliwości estetyczne, ale też takimi, wobec których duża część polskiego literaturoznawstwa musiała zajać określone stanowisko, aby umocnić bądź osłabić swoje oczekiwania wobec wiedzy na temat Shoah.

Żeby podczas analizy poszczególnych świadectw odbioru prawidłowo odtworzyć część kontekstu kulturowego, na jaką składają się prace polskich historyków i socjologów oraz tłumaczenia książek historyków zagranicznych, opublikowane po 1999 roku, warto jedynie wymienić tytuły owych rozpraw w kolejności ich ukazywania się. Są to: Sasiedzi Jana Tomasza Grossa (2000), „Szanowny panie Gistapo”. Donosy do władz niemieckich $w$ Warszawie i okolicach Barbary Engelking (2003), „Ja tego Żyda znam!” Szantażowanie Żydów w Warszawie 1939-1943 Jana Grabowskiego (2004), „Jestem Żydem, chcę wejść”. Hotel Polski w Warszawie, 1943 Agnieszki Haskiej (2006), Sprawcy, ofiary, świadkowie. Zagłada Żydów 1939-1945 Raula Hilberga (2007), „Moja żydowska dusza nie obawia się dnia sadu”. Mordechaj Chaim Rumkowski. Prawda i zmyślenie Moniki Polit (2012) i wreszcie Getto warszawskie. Przewodnik po nieistniejacym mieście Engelking i Jacka Leociaka (wydanie 2, zmienione, poprawione i rozszerzone: 2013). Ponieważ współczesne powieści o Zagładzie zaczęto postrzegać jako historyczne ${ }^{22}$, należy oczekiwać transferu wiedzy między pisarzami, badaczami przeszłości i czytelnikami, gotowymi przyjmować je nie tylko jako spójną prawdę, ale przede wszystkim jako konstrukt myślowy, oparty na źródłach, odnośnikach i przypisach.

Ostatnie z założeń poprzedzających analizę dotyczy sposobu rekonstruowania recepcji. W związku z tym, że w przypadku Tworek i Fabryki muchołapek rozwija się ona dwufalowo - najpierw pod wpływem recenzji, a później prac naukowych w omówieniu zostaną uwzględnione zasadnicze różnice między obiema falami. Opierać się ono będzie na dwu tytułowych kategoriach uznanych przez redaktorów pracy Stosowność i forma za kluczowe dla dyskursu o Zagładzie, nie zaś na pojęciach takich jak bohater, narrator czy fabuła, wokół których kiedyś prowadzono rozważania poświęcone recepcji powieści ${ }^{23}$.

Dla pierwszych recenzentów Tworek ogromnym kłopotem okazał się język utworu: podkreślano jego n i e s t o s o w n o ść, banalność, przesadna lekkość i nieadekwatność wobec prezentowanych zdarzeń. Michał Witkowski pisał, iż rzeczywistość przedstawiona jest nostalgicznie, czasem „drażniąco sentymentalnie” ${ }^{24}$, podkreślał fikcyjność i tekstualność świata Tworek, a także ukryte w nim, nie do końca jasne, sensy. Mieczysław Orski z kolei doceniał śmiałość wyobraźni pisarskiej Bieńczyka, chwalił go za wybór formy palimpsestu czy aluzje do Baśni tysiaca i jednej nocy, ale zupełnie nie uwzględnił warstwy historycznej dzieła. Twierdził np., że jego bohaterowie albo należą do polskiego podziemia, albo są Żydami ukrywa-

Stanowisko takie sformułował w 2011 r. P. R. Anderson, a pisał o nim F. J a me s on (The Antinomies of Realism. London - New York 2013, s. 259).

Zob. Głowińs ki, Konstrukcja a recepcja, s. 170.

M. Wit k ow ski, Majstersztyk. „Odra” 2000, nr 3, s. 125. 
jącymi się w „tolerancyjnej niemieckiej administracji szpitala tworkowskiego”25. Podobny problem sprawiała krytykowi melancholijna wymowa tekstu, na którą w „Megaronie” zwrócili uwagę Przemysław Czapliński i Piotr Śliwiński. Nieprzychylnie o powieści Bieńczyka wypowiedziała się Agnieszka Czachowska, pisząc w „Twórczości" o rozdmuchanych do granic wytrzymałości szczegółach, nieciekawych i sztucznych perypetiach uczuciowych bohaterów oraz o słabo opracowanym watku miłosnym, niegodnym autora Terminalu. „Banał codzienności zmienia się w banał tragedii" 26 - konstatowała recenzentka. Podobnie krytyczny stosunek do przedstawienia historii miała Kazimiera Szczuka:

Powieść Bieńczyka, odtwarzająca magiczny i kojący rytm stacji kolejki EKD (dziś WKD):... Reguły Malichy - Tworki - Pruszków... powraca do autentycznego „kawałka historii”. W żaden sposób nie można by się jednak tego domyśleć w spotkaniu z samym tekstem, skupionym na sposobach mówienia i, mocą autorskiej decyzji, zamkniętym we własnej literackości ${ }^{27}$.

Ostatecznie Szczuka doceniła w języku Tworek jego odnowicielską osobliwość, cechująca się brakiem zaufania do zastanych reguł, które nie nadawały się do opowiadania o Zagładzie:

Gra z językiem w „byle mówić” (bredzić, rymować, powtarzać, błaznować, szlochać etc.) zawsze jednak pamięta o swym własnym, podejrzanym, wieloznacznym statusie - aluzje i wszelkie ponure żarty podkopują wszelkie zadomowienie w języku...28

W odróżnieniu od poprzednich krytyków Katarzyna Nadana sformułowała w „Res Publice Nowej” kilka bardzo przychylnych sądów na temat Tworek. Większość dotyczyła, nie dostrzeżonego dotąd, problemu relacji polsko-żydowskich w czasie wojny. Recenzentka określiła je przy użyciu formuły „trauma utraty "takich samych-innych " ${ }^{29}$, naświetlając przy okazji fenomen przyjaźni między Polakami a Żydami, zasygnalizowany za pomoca porzucenia określeń narodowości bohaterów i zastąpienia ich imionami oraz poprzez zbudowanie analogii między losami polskimi i żydowskimi.

W przeciwieństwie do recenzji powieści Bieńczyka omówienia Fabryki muchołapek układają się w chór zgodnych pochwał, a ich przedmiotem jest przede wszystkim for m a: odnowicielska wobec tematu, nastawiona na dyskusję wokół historii, zdolna pokazać głęboka tęsknotę narratora za żydowską Łodzią i kontrowersje wokół czołowej postaci getta łódzkiego - Chaima Mordechaja Rumkowskiego. Inaczej niż Bieńczyk, Bart zastosował do opisu zdarzeń stosunkowo prosty, niekiedy ironiczny język, dzięki któremu uniknął krytyki pojawiającej się w recenzjach Tworek. Według Sławomira Buryły autor Rewersu:

łączy prawdę dokumentu i wyobraźni. Przy czym alternatywą dla żywiołu dokumentalnego nie jest kłamstwo, ale przekaz będący efektem kreacyjnych zdolności artysty. Ów aspekt kreacyjny nie stanowi nieokiełznanej siły, lecz zostaje podporządkowany - na ile to możliwe - prawdzie historycznej ${ }^{30}$. autora: Opowieści dla dorosłych i opowiastki dla niedorosłych. Wrocław 2010, s. 65-69.

M. Orski, O Jurku-ogórku głodnym przeżyć. „Nowe Ksiażki” 1999, nr 11, s. 16. Zob. też tego A. C z a c h ow s ka, „Dlaczego, psiakrew, polski?” „Twórczość” 1999, nr 12, s. 126.

K. Szc zu ka, Miłość w czasach Zagłady. „Tygodnik Powszechny” 1999, nr 27, s. 14. Ibidem.

K. N a d a n a, U Pana Boga za piecem. „Res Publica Nowa” 1999, nr 7/8, s. 105.

S. Buryła, Bez wyroku. „Więź” 2009, nr 10, s. 132. 
Niezwykle istotną rolę, zdaniem badacza, odgrywa tu także ironia: gdyby nie ona, „można by się zastanawiać, czy Fabryka muchołapek to nic więcej ponad sprawnie warsztatowo napisaną książkę dla niezbyt wybrednego odbiorcy"31.

Maciej Robert, Krzysztof Cieślik i Włodzimierz Paźniewski podkreślają „dobra robotę" prozaika, jego wysoka, choć nie zawsze docenianą, pozycję w literaturze i intencjonalność jego sztuki ${ }^{32}$ (Fabryka muchołapek to według nich „utwór, w którym rzeczywiście o coś chodzi”33). Dariusz Nowacki jeszcze wyraźniej pokazuje nowatorstwo dzieła Barta:

To afirmatywna, wolna od lamentów wędrówka po mieście, które Andrzej Bart autentycznie kocha [...]. Fabrykę muchołapek można chyba wpisać na krótką listę polskich powieści, w których [...] doszło do odnowienia tematyki związanej z Zagładą. [...] czyta się z przejęciem i podziwem² ${ }^{34}$.

Recenzenci rozpoznają w Fabryce muchołapek cechy powieści postmodernistycznej. Nie przeszkadza im to jednak w docenieniu dzieła Barta i uznaniu połączenia postmodernizmu z Zagładą za odpowiedni wybór.

Postmodernistyczna konwencja stosowana przez tego pisarza od samego początku jego błyskotliwej literackiej kariery pozwala przecież mieszać nie tylko plany historyczne i ożywiać umarłych, ale też inkrustować główny wątek narracyjny powieści przypadkowymi cytatami.

- pisze Gustaw Romanowski ${ }^{35}$. Tylko w recenzji Magdaleny Góreckiej pojawiają się wątpliwości dotyczące właściwego wyboru formy: „Czy można w taki sposób pisać o Zagładzie?”; „Czy sąd nad przywódca łódzkiego getta to dobry temat na powieść w duchu postmodernistycznym?"36. Rozwiewa je jednak Paulina Małochleb:

Doskonałość Fabryki muchołapek polega na tym, że nie jest ona kolejną „holocaustową szminką", historią, jakie publikuje się nieustannie, bo jest na nie popyt. Nie ma lepszego przepisu na bestseller, niż napisać powieść osadzoną w czasie wojny... Tymczasem powieść Barta nie powstała na żadne społeczne zamówienie ${ }^{37}$.

Kierunek odczytań naukowych obu powieści okazuje się odwrotny niż w przypadku recenzji: docenia się Bieńczyka i z podejrzliwością analizuje strategię twórczą Barta. Przyczyny tej zmiany, szczególnie że zarówno po stronie krytyków, jak i autorów studiów można znaleźć uczonych, nie zawsze są od razu zrozumiałe. W jednym z pierwszych artykułów poświęconych Tworkom Maciej Leciński nazywa prozę Bieńczyka „udana próbą znalezienia nowego języka dla opowieści o Holocauście" ${ }^{38}$. Określenie to wolno ocenić jako symboliczne. Po latach wahań i wątpliwo-

Ibidem.

M. Robert, rec.: A. Bart, Fabryka muchołapek. Warszawa 2010. „Notes Wydawniczy” 2009, nr 1. - K. Ci éślik, Proces, którego nie było. „Polityka”, 28 XI 2009. Na stronie: http://www.polityka.pl/tygodnikpolityka/kultura/ksiazki/274600,1,recenzja-ksiazki-andrzej-bart-fabrykamucholapek.read (data dostępu: 14 X 2019).

W. Paźni ew s ki, Trybunał Barta. „Przegląd Polityczny” 2009, nr 94, s. 157.

D. N ow a c ki, Z niezgody na nieobecność. „Tygodnik Powszechny” 2008, nr 48.

G. Ro m a n o w s ki, Proces bez wyroku. Powrót Rumkowskiego. „Kronika Miasta Łodzi” 2009, z. 2, s. 271.

M. Gó r e c k a, Sprzedać duszę za złudę przetrwania. „Akcent” 2009, nr 3, s. 138, 140.

P. Mało chleb, Murarz buduje, a ja majaczę. „FA-art” 2009, nr 1/2, s. 51.

M. Le c ińs ki, „Likwidacja przewagi”. Praca żałoby i empatia w „Tworkach” Marka Bieńczyka. „Teksty Drugie” 2001, nr 1, s. 156. 
ści co do wyniku poszukiwań dyskursu, który zdołałby unieść doświadczenie i pamięć Zagłady, literaturze udaje się znaleźć taką opowieść - i to nie w sensie historycznym (tu Tworki mówią niewiele, unikając nawet prostego wskazywania odniesien pozatekstowych, zawartych w historii Sonii, Jurka i Marcela, oraz kontekstu tych fabuł), ale literackim, czyli takim, o jakim za pośrednictwem Barthes'a w Rue des Écoles oznajmiał Bieńczyk, pisząc o idei powieściowości.

Analizujący Tworki badacze skupili się więc wokół kilku pojęć, podyktowanych czytanymi w latach dwutysięcznych lekturami filozoficznymi, narratywistycznymi i psychoanalitycznymi: języka i jego metonimicznych właściwości (jak za Frankiem Ankersmitem pisze Arkadiusz Morawiec) oraz jego manowców i bezdroży (Aleksandra Ubertowska), żałoby i melancholii (Leciński, Przemysław Czapliński), narracyjnego fetyszyzmu i kultury posttraumatycznej (Katarzyna Bojarska), niewyrażalności w powieści postmodernistycznej (Maciej Płaza), retoryki czasowości (Jakub Muchowski), idylliczności (Marek Zaleski), postpamięci (Marta Czemarmazowicz, Anna Mach), mesjanizmu (Emilia Padoł), miłości (Bartłomiej Krupa) ${ }^{39}$. Za pomoca wymienionych kategorii, $z$ jednej strony, przedstawiono Tworki jako totalne zerwanie $\mathrm{z}$ oświeceniową tradycja pisania o katastrofie (Zaleski), $\mathrm{z}$ drugiej - widziano w nich naruszenie granic pooświeceniowej praktyki artystycznej, uragające jej etyczności i pamięci o ofiarach (Ubertowska). Bardzo istotne okazało się również to, że Bieńczyk zdołał jednocześnie stworzyć powieść o języku Zagłady i uniknąć mówienia o niej, a zatem tego, co od początku stanowiło słabość takich powieści. „Bieńczyk postanawia mówić o Zagładzie za pomocą... niemówienia o Zagładzie”, pisał Piotr Marecki ${ }^{40}$. Czapliński wtórował: „Powieść Bieńczyka wydaje się próbą ukazania konkretnego jezzyka jako przyczyny niezrozumienia Zagłady” ${ }^{41}$. „W powieści nie mówi się wprost o Zagładzie, Żydach, szmalcownikach...”, dowodziła Chmielewska ${ }^{42}$. Krupa zaś konkludował: „A [...] najważniejsze rzeczy dzieją się - wszyscy

A. M o r a w i e c, Holokaust i postmodernizm. O „Tworkach” Marka Bieńczyka. W: Literatura w lagrze, lager $w$ literaturze. Fakt - temat - metafora. Łódź 2009, s. 347-363. - A. U b e r tow s ka, Świadectwo - trauma - głos. Literackie reprezentacje Holocaustu. Kraków 2007, s. 289-296. - L e c ińs ki, op. cit. - P. C z a plin s k i, Zagłada - niedokończona narracja polskiej nowoczesności. W zb.: Ślady obecności. Red. S. Buryła, A. Molis ak. Kraków 2010, s. 371-373. - K. Bojar ska, Historia Zagłady i literatura (nie)piękna. „Tworki” Marka Bieńczyka $w$ kontekście kultury posttraumatycznej. „Pamiętnik Literacki” 2008, z. 2. - M. Płaza, Tekst doświadczenia, doświadczenie tekstu - narracje Marka Bieńczyka. W zb.: Narracje po końcu (wielkich) narracji. Kolekcje, obiekty, symulakra. Red. nauk. H. Gosk, A. Zi eni ewicz. Warszawa 2007. - J. M u ch ow ski, Figury czasowości w „Tworkach” Marka Bieńczyka. „Teksty Drugie” 2006, nr 3. - M. Zale ski, Echa idylli w literaturze polskiej doby nowoczesności i późnej nowoczesności. Kraków 2007, s. 277-310. M. C z e marmazowi cz, Podmiot literacki wobec doświadczenia (post)traumy. Reprezentacje Holokaustu w perspektywie postpamięci (na podstawie „Zagłady” Piotra Szewca, „Tworek” Marka Bieńczyka i „Każdy przynióst, co miat najlepszego” Mieczysława Abramowicza. W zb.: Podmiot $w$ literaturze polskiej po 1989 roku. Antropologiczne aspekty konstrukcji. Red. nauk. Ż. Na lew aj k. Warszawa 2011. - A. M a ch, Świadkowie świadectw. Postpamięć Zagłady w polskiej literaturze najnowszej. Warszawa-Torun 2016. - E. P a d o ł, Język i mesjanizm: (post)konteksty a problematyka żydowska w „Tworkach” Marka Bieńczyka. W zb.: Polacy-Żydzi: kontakty kulturowe i literackie. Red. E. Prokop-J aniec. Kraków 2014. - Krupa, op. cit. 
interpretatorzy powieści są tu w zasadzie zgodni - w obrębie samego języka"43. Języka, czyli czegoś, co stoi w opozycji do tego (tych), czego (których) nie ma. „Lepiej pozostać w ludzkiej przestrzeni, zakończyć opowieść gestem afirmacji, niż zaciekle drążyć nieobecność”, pouczał Zaleski ${ }^{44}$. Na koniec powtórnie Leciński:

Tworki Marka Bieńczyka są powieścią przywracająca wiarę w sens literatury, okazuje się bowiem, że umiejętność współodczuwania, „wsłuchiwania się” w drugiego można wykorzystać w prozie do rozpoznania własnej traumy, własnej utraty. Dla Bieńczyka pisanie, od dawna uznawane za terapię, a dla odbiorcy lektura - okazać się mogą (to kolejna dobra wiadomość) lekiem na „chorobę żałoby”45.

Warto odnotować, że wśród głosów aprobatywnych zabrakło jakiejkolwiek analizy zestawiającej powieść z wiedzą historyczną. Wprawdzie czas publikacji Tworek przypadł jeszcze na koniec lat dziewięćdziesiątych XX wieku, ale już rok później pojawili się Sasiedzi Grossa, a wraz z nimi nastała zupełnie nowa era dyskusji o Zagładzie w Polsce, skoncentrowana na polskim sprawstwie i nadszarpniętym wizerunku stosunków polsko-żydowskich podczas wojny. Echa owej debaty, ciągnącej się do dzisiaj, nie są słyszalne w omawianych artykułach. W przeciwnym razie ich ton, pełen przekonania o tym, że Bieńczykowi udało się uratować w powieści wartości humanistyczne, nie byłby tak spokojny.

W zupełnie inną stronę zwrócili się badacze Fabryki muchołapek. To, co jeszcze dla recenzentów powieści stanowiło jej zaletę (jak misterna konstrukcja), teraz okazało się wywoływać wrażenie repetycji i déjà vu. Jak pisała Krystyna Pietrych: „cały arsenał zintensyfikowanych gier tekstowych [...] jakoś zawodzi” ${ }^{46}$. Badaczka wysunęła wobec książki Barta kolejne cztery zarzuty: jest ona zbiorem gotowych formuł, sąd nad bohaterem ma charakter pozorny (w istocie pokazuje się go jak postać negatywna), pogwałcone zostają granice etyczne kreacji („Czy można mówić Z wnętrza jadącej ciężarówki-komory, gdy już czuć spaliny? Odpowiedź nie jest dla mnie oczywista. Mam poczucie jednak, że dochodzi w tym przypadku do jakiegoś naruszenia i przekroczenia przestrzeni ciszy i milczenia”), a „cała uruchomiona przez Barta strategia literacka gubi gdzieś straszność, o której stara się opowiadać" 47 .

Także dla Danuty Szajnert szarże fabularne Barta okazały się złudną strategia pisania o Zagładzie:

I nie chodzi tu jedynie o manifestowaną w Fabryce muchołapek metatekstualność czy samoobronny ironiczny dystans i ton aż nazbyt, wydawałoby się, lekki: niemal na pograniczu stosowności, zważywszy na prezentowaną problematykę ${ }^{48}$.

Powieść Barta uznano za narcystyczny popis pozbawionego wiedzy historycznej

mannstadt Getto (rekonesans). Cześć druga. „Białostockie Studia Literaturoznawcze” nr 6 (2015), s. 22 . 
autora, który ani dobrze nie opanował reguł gatunku powieści postmodernistycznej ${ }^{49}$, ani nie posiadł wystarczajacej wiedzy na temat Litzmannstadt Getto. W numerze szóstym rocznika Centrum Badań nad Zagładą Żydów IFiS PAN „Zagłada Żydów. Studia i Materiały" zainicjowano dyskusję wokół Fabryki muchołapek. Justyna Kowalska-Leder skrytykowała warstwę poznawczą powieści:

Owszem, [czytelnik] może podziwiać wiedzę i kunszt pisarski Andrzeja Barta, ale za sprawą jego powieści niczego nowego się nie dowie, nie zostanie też emocjonalnie z niczym nowym skonfrontowany. Problem tkwi bowiem w tym, że autor Fabryki muchołapek nie podejmuje się najtrudniejszego, a zarazem najważniejszego $\mathrm{z}$ perspektywy czytelnika zadania - próby zrozumienia postępowania Chaima Rumkowskiego, a więc odpowiedzi na przynajmniej część pytań, które narosły wokół jego osoby ${ }^{50}$.

Z kolei Jacek Leociak za nieudaną uznał całą koncepcję powieści Barta, redukując jej postmodernistyczną estetykę do narcystycznego podrabiania dokumentu:

Książka Barta jest dla mnie przykładem kiczu narcystycznego. Jest w pół drogi między literaturą a dokumentem, powieścią a relacją, zeznaniem a zapisem snu. Jest manifestacyjnie „pomiędzy” dyskursami, gatunkami, prawda a zmyśleniem. W stu procentach spełnia zatem model postliteratury w czasach postnowoczesnych. Niczym więc nie zaskakuje - jej poetyka jest doskonale przewidywalna, aż do bólu „posttradycyjna” ${ }^{1}$.

Gruntownej analizy powieści podjęła się Polit we wspomnianej monografii. Nazwała Fabrykę muchołapek „straconą, może ostatnią okazją, by w Polsce ukazała się rzetelna i zarazem ciekawa powieść o MChR jako człowieku i Przełożonym Żydów w łódzkim getcie" 52 . Równocześnie, przywołując bardziej niszowe źródła i opracowania historyczne, Polit zaprojektowała możliwą powieść o Rumkowskim, nie osądzająca, dopracowaną faktograficznie, mniej jednoznaczną.

Autorami najobszerniejszych i najsurowszych omówień krytycznych Fabryki muchołapek okazali się badacze najważniejsi dla tematu getta w Łodzi. Część z nich, jak Agnieszka Izdebska, Pietrych czy Szajnert, pracuje w Uniwersytecie Łódzkim, pozostali - Kowalska-Leder, Leociak, Polit - są związani z Centrum Badań nad Zagładą Żydów IFiS PAN. Oba środowiska dowiodły, że „Fabryka muchołapek, tak oczekiwana i chwalona, jest dobra powieścią o miejscu, historii i osobistym do nich stosunku artysty. Niestety, jako opowieść o MChR [...] jest chybiona" 53 .

Mimo widocznych różnic porównywane utwory wiele łączy. Na podstawie przytoczonych i omówionych opinii można stwierdzić, iż opis ich cech strukturalnych, rozwiązań narracyjnych (jak przemieszanie czasów wypowiedzi) oraz odniesień filozoficznych (do Derridiańskiej koncepcji języka czy kategorii wzniosłości rozu-

A. Izdebska i D. Szajnert (The Holocaust-Postmemory - Postmodern Novel: „The Flytrap Factory” by Andrzej Bart, „Tworki” by Marek Bieńczyk and „Skaza” by Magdalena Tulli. W zb.: The Holocaust in the Central European Literatures and Cultures since 1989 / Der Holocaust in den mitteleuropäischen Literaturen und Kulturen seit 1989. Red. R. Ibler. Stuttgart 2014, s. 143) porównały Fabrykę muchołapek do kieszonkowego słownika i wiedzy w pigułce.

J. Kowals ka-Le d e r, rec.: A. B a rt, Fabryka muchołapek. Warszawa 2010. „Zagłada Żydów. Studia i Materiały" nr 6 (2010), s. 322.

51 J. Le o ci a k, O nadużyciach $w$ badaniach nad doświadczeniem Zagłady. Jw., s. 14.

52 M. Poli t, „Moja żydowska dusza nie obawia się dnia sadu”. Mordechaj Chaim Rumkowski. Prawda i zmyślenie. Warszawa 2012, s. 203. 
mianej za Lyotardem jako silny, splatający w sobie przyjemność i ból dwuznaczny afekt ${ }^{54}$, który wywołuje w podmiocie uczucie analogiczne do tego charakterystycznego dla sytuacji śmierci i wybawienia的) jest podobny, natomiast różne sa jego oceny. Za aprobatą wobec projektu Bieńczyka stoi docenienie języka powieści, potraktowanego ostatecznie jako stosowny dyskurs o Zagładzie. $Z$ kolei za negacje konceptów Barta odpowiada niewłaściwie pomyślana narracja historyczna. Omówione ślady odbioru można zaprezentować w dwu grupach: pierwszą, odnoszącą się do Tworek, anonsowałoby pytanie o estetykę (jak się przedstawia Zagładę?), druga, odsyłająca do Fabryki muchołapek, warto scharakteryzować za pomoca pytania o historię (Co się przedstawia? Jakie fakty z życia Rumkowskiego zostały przez pisarza uwzględnione? Czy oparł się on na wystarczającej liczbie źródeł historycznych, by adekwatnie zbliżyć swoją wizje przeszłości do prawdy?). Zrozumienie przyczyn tak różnego wartościowania bardzo podobnych chwytów formalnych i koncepcji myślowych ułatwić mogą teoria narratywistyczna Ankersmita i zaproponowane przez niego pojęcia reprezentacji historycznej, wzniosłości oraz traumy.

Za wzmożone w ostatnich dekadach zainteresowanie historyków Zagładą odpowiadają ograniczenia zwrotu lingwistycznego, który doprowadził do uczynienia z języka warunku „możliwości wszelkiej wiedzy i rozumienia historycznego”, ale jednocześnie nie podołał rozumieniu samej Zagłady. „Nie powinno nas wręcz dziwić” - wyjaśnia Ankersmit - „Że Holocaust stał się największym wyzwaniem dla tego transcendentalizmu lingwistycznego", a „zwrot lingwistyczny napotka swoją nemezis w postaci problemu przedstawiania Holocaustu" ${ }^{56}$. Wszelkie językowe unaocznienia przeszłości, w tym także powieść, należy rozpatrywać w kategoriach narracji historycznych, będacych reprezentacjami minionego, a zatem „re-prezentacjami" nieobecności. Wprawdzie - poucza dalej Ankersmit - powinno się dołożyć starań, aby wiarygodnie zastępowały one nieobecna przeszłość, ale właśnie dlatego, że są tylko jej substytutami, nie sposób ich oceniać jako prawdziwych czy fałszywych (jak zdań w logice) ${ }^{57}$. Narratywizacja historii odbywa się poprzez narratywizację traumy, czyli włączenie przeszłych zdarzeń w obręb prywatnych doświadczeń podmiotu decydującego o reprezentacji. Wskutek tego dochodzi do separacji historii i jej przedstawienia oraz do doświadczenia wzniosłości (będącej reakcją na ruch rozdzielenia). Przeszłość staje się częścią czasu teraźniejszego, traci ostrość, nie jest już niebezpieczna, a podmiot może sprawować nad nią kontrolę ${ }^{58}-$ dzięki niezliczonym własnym narracjom, rozbijającym monopol zinstytucjonalizowanej

J.-F. Ly o ta rd, Odpowiedź na pytanie: co to jest postmodernizm? W zb.: Postmodernizm. Antologia przekładów. Wybór, oprac., przedm. R. Ny c z. Wyd. 2. Kraków 1998, s. 55 (przeł. M. P. M a rkowski).

J.-F. Ly o ta rd, Wzniosłość i awangarda. Przeł. M. Bień czy k. „Teksty Drugie” 1996, nr 2/3, s. 182.

F. An kers mit, Postmodernistyczna „prywatyzacja” przeszłości. W zb.: Narracja, reprezentacja, doświadczenie. Studia z teorii historiografii. Red., wstęp E. D o mań s ka. Kraków 2004, s. 381 (przeł. M. Za pędowska).

F. An ker s mit, Wprowadzenie do wydania polskiego. W zb.: jw., s. 32 (przeł. E. D o mań s ka). Zob. F. A n ke r s mit, Wzniosłe odłaczenie się od przeszłości. W zb.: jw., s. 356 (przeł. J. B e n edyktowicz, przekł. przejrzał M. Bańkowski, przekł. uzup. E. Domańska). 
historii i oddającym pierwszeństwo pamięci („sprywatyzowana pamię́”) oraz przeciw-wspomnieniom (counter-memories) ${ }^{59}$.

Sygnałami kontroli przeszłości przedstawionej w Tworkach okazały się, poczynione przez Bieńczyka, aluzje kulturowe. Najwięcej pisali o nich Zaleski, porównujący sielankowość powieści z melancholijnymi obrazami Antoine'a Watteau i The Invention of Liberty Jeana Starobinskiego, Leciński, wyczytujący z Tworek reinterpretację mitu arkadyjskiego, Szczuka i Ubertowska, krytykujące sposób, w jaki Bieńczyk przypomniał fantazmat pięknej Żydówki, czy Bojarska i Morawiec, objaśniający postać Antyplatona i tradycji platońskiej w dziele. Dowiedziono, że Bieńczykowi udało się wykreować powieść o Zagładzie na miare naszej kultury; że znalazł on mimo wszystko modus, aby, nie kwestionując jej najtrwalszych zasad i wartości, opisać Zagładę za pomocą istniejących mitów, toposów i stylów. Opublikowana prawie dekade później Fabryka muchołapek została przeczytana głównie z perspektywy przedstawianej przez nią historii, chociaż i tutaj krytyka doskonale poradziła sobie $z$ wychwyceniem wszystkich aluzji literackich i intertekstów ${ }^{60}$. $Z$ pewnością Bartowi było bliżej do historiograficznej koncepcji powieści Lindy Hutcheon $-\mathrm{z}$ jej swobodnym stosunkiem do faktów, rozpadającą się forma i rozumieniem archiwum jako miejsca spotkania historii z literatura ${ }^{61}$. A to musiało także oznaczać, że do pisania o Zagładzie wybrał autor styl „źle obecny" w Polsce, utożsamiany z blagą i rozrywką, daleki od umacniania - nawet poprzez wcześniejszą dekonstrukcję - przeświadczenia o doniosłości kultury narodowej 62 .

Rekonstrukcja recepcji prozy Bieńczyka i Barta uzmysławia, iż pod koniec lat dwutysięcznych porzucono namysł nad stosownością i formą na rzecz pytań o historię. Powróciły kwestie powinności etycznych literatury i jej odpowiedzialności za rozliczanie przeszłości, a także oceny kontrowersyjnych postaw Polaków i Żydów w czasie wojny. Mimo że rośnie liczba prac historycznych, w rozprawach naukowych na temat Tworek nie widać tego zwrotu. Preferowany styl odbioru powieści o Zagładzie po 1989 roku odnosi się do problemów związanych głównie z estetyką, $\mathrm{z}$ jezzykiem, $\mathrm{z}$ funkcją retoryki, $\mathrm{z}$ rozumieniem powieściowości, $\mathrm{z}$ granicami reprezentacji, z tym, co należy uznać za niewyrażalne. Zdecydowanie gorzej przyjął się styl związany z postmodernistycznym pojmowaniem historii, jakie można znaleźć w rozprawach Hutcheon czy Briana McHale'a: parodię i bezceremonialne przekręcanie faktów ${ }^{63}$ oceniono jako słabość artystyczną powieści, a nie jej odpowiedź na wyzwanie rzucone literaturze przez Zagładę.

An ke rs mit, Postmodernistyczna „prywatyzacja” przeszłości, s. 373.

Zob. B. D ą b row s ki, Postpamięć, zależność, trauma. W zb.: Kultura po przejściach, osoby z przeszłością. Polski dyskurs postzależnościowy - konteksty i perspektywy badawcze. Red. R. Ny cz. Kraków 2011.

L. H u t c h e o n, Historiograficzna metapowieść: parodia i intertekstualność historii. W zb.: Postmodernizm, s. 383 (przeł. J. Margańs ki).

K. U n iłow s ki, Czym sa fabulacje i dlaczego sięje lekceważy? W: Prawo krytyki. O nowoczesnym i ponowoczesnym pojmowaniu literatury. Katowice 2013.

B. M c Hale, Powieść postmodernistyczna. Przeł. M. Pła za. Kraków 2012, s. 24. 


\section{Abstract \\ MARTA TOMCZOK University of Silesia, Katowice ORCID: 0000-0001-9512-007X \\ STYLES OF RECEPTION OF THE POLISH NOVEL ABOUT THE SHOAH \\ ON MAREK BIEŃCZYK'S "TWORKI" AND ANDRZEJ BART'S "FABRYKA MUCHOŁAPEK" ("FLYTRAP FACTORY")}

Employing Michał Głowiński's concept of styles of reception, Tomczok researches the reception of two Polish novels about the Shoah, namely Marek Bieńczyk's Tworki (1999) and Andrzej Bart's Fabryka muchołapek (Flytrap Factory, 2008). The analysis reveals the following conclusions: in the first decade of the $21^{\text {st }}$ century, a shift in understanding the role of the novel about the Shoah took place, as the novel-a disregarded genre and having many reservations-became a subject of intense debates about the representation and understanding of the Holocaust and, furthermore, the aesthetic categories used for evaluating the literature about the Shoah lost their significance. After the year 2008, history has become the most crucial category among the Polish scholars, alongside its interpretations and modes of expression. 